Sudipta Basu' / Gregory B. Waymire ${ }^{2,3}$

\title{
Historical Cost and Conservatism Are Joint Adaptations That Help Identify Opportunity Cost
}

${ }^{1}$ Fox School of Business, Temple University, Philadelphia, PA, USA, E-mail: Sudipta.Basu@temple.edu

${ }^{2}$ Coizueta Business School, Emory University, Atlanta, CA, USA, E-mail: Waymire@chapman.edu

${ }^{3}$ Argyros School of Business, Chapman University, Orange, CA, USA, E-mail: Waymire@chapman.edu

\begin{abstract}
:
Braun (The ecological rationality of historical costs and conservatism. Accounting, Economics and Law: A Convivium, this issue) argues that the traditional accounting principles underlying the revenue-expense approach such as Historical Cost and Conservatism are ecologically rational in that they help organizations survive better in uncertain economic environments. More importantly, Braun argues that the revenue-expense approach generates new private information, which informs markets and makes them more effective (Hayek, 1945, The use of knowledge in society. The American Economic Review, 35(4), 519-530), as opposed to merely reflecting back market data under the asset-liability approach (e.g. Sunder, 2011, IFRS monopoly: The Pied Piper of financial reporting. Accounting and Business Research, 41(3), 291-306). We try to explicate the nature of the new private information generated jointly by Historical Cost and Conservatism, and how this information facilitates the survival of individual entrepreneurs and organizations in market competition.
\end{abstract}

Keywords: conservatism, discovery process, historical cost, knowledge problem, opportunity cost DOI: 10.1515/ael-2016-0070

Table of contents

1. Introduction

2. The knowledge problem

3. Opportunity cost

4. Accounting principles and the search for better courses of action

5. Joint adaptations: Historical Cost and Conservatism

6. Implications for Accounting Regulation

7. Concluding thoughts

8. References

On the Evolutionary Advantage of Cost Accounting and Conservatism

1. Braun, E. (2016). The Ecological Rationality of Historical Costs and Conservatism. doi: https://doi.org/10.1515/ael-2015-0013.

2. Basu, S. \& Waymire, G. (2017). Historical Cost and Conservatism Are Joint Adaptations That Help Identify Opportunity Cost. doi: https://doi.org/10.1515/ael-2016-0070.

3. Saito, S. \& Fukui, Y. (2016). Whither the Concept of Income? doi: https://doi.org/10.1515/ael-2016-0013.

4. Tang, V. (2017). The Role of Accounting and the Debate between Historical Cost and Fair Value. doi: https://doi.org/10.1515/ael-2016-0066.

5. Baker, C. (2016). Commentary on Braun's "The Ecological Rationality of Historical Costs and Conservatism" doi: https://doi.org/10.1515/ael-2016-0070.

6. Braun, E. (2017). Concluding Remarks on the Symposium on the Evolutionary Advantage of Cost Accounting and Conservatism. doi: https://doi.org/10.1515/ael-2017-0049.

Sudipta Basu is the corresponding author.

(c) 2019 Walter de Gruyter $\mathrm{GmbH}$, Berlin/Boston.

This content is free. 
I have two basic propositions that directly bear on accounting: (1) Accounting is an integral part of the structure of every organization, and (2) a fundamental understanding of why accounting practices evolve as they do and how to improve them requires a deeper understanding about organizations than now exists in the social sciences.

Jensen (1983, p. 319)

It is important to remain sensitive to the fact that human institutions and most decision making is not guided primarily, if at all, by constructivism. Emergent arrangements, even if initially constructivist in form, must have survival properties that take account of opportunity costs and environmental challenges invisible to our modeling efforts.

Smith (2003, p. 468)

Financial reporting is not an end in itself but is intended to provide information that is useful in making business and economic decisions - for making reasoned choices among alternative uses of scarce resources in the conduct of business and economic activities.

Financial Accounting Standards Board (2008, Paragraph 9)

\section{Introduction}

Braun (this issue) synthesizes and extends previous arguments for why aspects of the revenue-expense approach to accounting, which emerged in practice before the advent of modern regulation, are valuable for individuals and markets. He argues that accounting principles such as Historical Cost and Conservatism are similar to widespread human behavior captured in neuroscience and behavioral economics (e. g. Dickhaut et al., 2010; Hirshleifer \& Teoh, 2009), that evolved by trial-and-error adaptation over millions of years. His major insight is that the revenue-expense approach provides new private data to the capital market that informs security prices (Hayek, 1945). In pulling these strands together, Braun (this issue) builds a cogent argument for why the current monopolistic regulators of accounting, with their preference for an asset-liability approach coupled with fair value measurement, could harm the long-term survival of firms and markets, similar to Basu and Waymire (2008, 2010), Dye and Sunder (2001) .

Barker and Penman (2016) argue that choices between accounting methods such as capitalizing versus expensing or amortization versus impairment are driven by variation in realization uncertainty, which is the likelihood that current expenditures will eventually generate revenues. Although realized cash flows are always recorded, the treatment of unrealized future cash flows varies across Historical Cost, Conservatism and Fair Value measurement bases. Unrealized cash flows are never (always) recorded under pure Historical Cost (pure Fair Value) measurement, while only negative unrealized cash flows (unrealized losses) are recorded under pure Conditional Conservatism (Basu, 1997; Bliss, 1924, p. 110). ${ }^{1}$

In this essay, we argue that the adaptive value of Historical Cost and Conditional Conservatism (hereafter Conservatism) depends critically on their interaction with one another in helping identify, classify, and estimate opportunity costs, which are important for a firm's survival. These estimates constitute local knowledge, which through the trading activities of households and firms feed into prices and help product markets clear, even though none of the participants fully grasp the production and distribution system of the economy a.k.a. the knowledge problem (Hayek, 1945). Although Braun cogently argues why accounting principles such as Historical Cost and Conservatism benefit both individuals and securities markets, he does not explicitly develop the arguments for why firms benefit from these principles.

The key to our argument is to recognize that most firms generate value from exchange transactions spread over time, often measured as the operating cycle (time to convert inventory to cash) and the trade or cash conversion cycle (time from payment for raw materials bought on credit to collection of cash from credit sales). In reviewing choices that span multiple periods, it is not enough to compare outcomes to expectations in just the last period, as Fair Value measurements would. Rather, we have to jointly analyze actions and outcomes in the final, intermediate and initial periods. Historical Cost transaction data provide the memory to estimate the multi-period net benefit, which helps entrepreneurs discover better current actions. Absent transaction records that detail why past choices were made, entrepreneurs use heuristics like "sunk cost" to identify better choices. Further, Conservatism through impairments provides accounting "markers" of avoidable transactions that reduce survival prospects on average. Through this on-going local decision-making, financing flows toward 
higher valued investments and economic efficiency improves, enabling higher growth and increased welfare. These effects are reinforced by the contracting efficiencies engendered by Historical Cost and Conservatism (e. g. Ball, 1989).

We describe the three building blocks of our argument - the knowledge problem, opportunity cost, and accounting principles - in the next three sections and how they arise from the interactions of individuals, organizations, and markets. We next explain how Historical Cost and Conservatism jointly help firms improve their survival odds, discuss the implications of our argument for accounting regulation, and finally conclude.

\section{The knowledge problem}

As Braun (this issue) discusses, neoclassical economic theory generates testable predictions by making strong assumptions including perfect competition, complete markets, costless information, infallible memory, unlimited computing power, and omniscient and maximizing actors with stable and well-shaped preferences. Under these assumptions, general equilibrium theory shows that the market system will efficiently utilize resources and maximize social welfare. The knowledge problem is that actual market participants know little because information is costly to procure and process. Thus, the standard models predict that market economies are inefficient because uninformed real-life market participants will choose poorly.

In these models, utility-generating consumption occurs only in households while only profit-seeking firms produce. These assumptions let a researcher calculate and prescribe the optimal decisions for each actor in the model, and predict equilibrium outcomes for the system (Walras, 1874). Single-period general equilibrium is generalized to multi-period general equilibrium by assuming that all goods can be bought or sold for delivery on any future date at any specific location (Arrow \& Debreu, 1954; McKenzie, 1954). Given a complete set of state-contingent prices, individuals choose today for both today and all future periods.

These assumptions are ideal rather than realistic, but Friedman (1953) argued that this is not fatal for economic analysis if the resulting theory predicts well. Stated differently, the stylized assumptions of neoclassical economic theory constitute a coherent set of sufficient conditions for the existence of general equilibrium, but none of them may be necessary. For example, Tintner (1941a, 1941b) observed that maximizing behavior is meaningless in an uncertain or ambiguous world (Knight, 1921) while Simon (1956), p.129 argued, "Evidently, organisms adapt well enough to 'satisfice'; they do not, in general, 'optimize'." However, Alchian (1950) and Becker (1962) showed that many economic laws will hold even if consumers do not maximize utility or firms do not maximize profits. Similarly, Gode and Sunder $(1993,1997)$ demonstrated that 'zero-intelligence' traders achieve competitive equilibrium and allocative efficiency in experimental markets because the rules of the marketplace substitute for individual rationality in generating efficient outcomes (Coase, 1988; Sunder, 2004). More condition) to benefit others through market exchanges.

However, the unrealistic assumptions cause trouble if and when the theoretical solutions are implemented (e. g. Coase, 1982; Simon, 1978). In the early twentieth century, many economists believed that planned socialist economies could outperform market economies if experts solved simultaneously the Walrasian equations of demand and supply, and thus, coordinated production plans (e. g. Barone, 1908). ${ }^{2}$ However, Hayek (1935) observed that no individual or small group could know anywhere near all the demand and supply data needed to compute the millions of production plans for all the initial, intermediate and final products in even a small economy. Buchanan (1979) and Schelling (1978) pointed out that general equilibrium theory assumes that people have stable preferences, and thus, cannot learn and develop, which is clearly unrealistic. Similarly, the assumption of known production technology implies that technology cannot change, but technological innovation is the crucial ingredient for economic growth in the Schumpeter (1942) gale of creative destruction or the Solow growth model (Solow, 1956; Swan, 1956).

If neoclassical price theory describes market economies poorly, then how do consumers and producers coordinate without expert guidance? Hayek (1945) explains that the price mechanism coordinates plans without requiring centralized knowledge or intensive computation. People choose between current and future consumption (i. e. saving), using interest rates and other forward prices to benchmark their decisions. Each person buys or sells a product using her knowledge of local demand and supply conditions. Consumers choose between substitute products (e. g. different vegetables) by comparing each one's expected value with the purchase price, accounting for any synergies in consumption (e. g. recipes). Prices change to clear local markets, but prices for a given product vary geographically because of transportation costs, local taxes, customer accessibility and other factors, especially information costs that hinder arbitrage (Stigler, 1961).

Individuals play an important dual role as producers that is largely ignored in general equilibrium theory, which only models firms (Demsetz, 1983). However, firms are composed of people, so both demand and supply 
ultimately reflect individuals' choices. People choose whether and how much to participate in the market economy, work outside it (e. g. running a household and raising a family) and/or enjoy leisure (e. g. in retirement). If people produce for the market, they choose whether to run their own businesses as entrepreneurs or join another business as partners or employees. Joining another business trades off some rights to make production decisions for potentially more stable income (Coase, 1937).

A producer's decision problem is more difficult if the production process extends across several periods and future selling prices are uncertain (e. g. a farm), and even more complicated when intermediate products can be bought and sold. The multi-period decision problem is simpler for monopolists, who can estimate the benefits and costs of each available production opportunity based on their own past experience (and not worry about competing producers). Monopolists study current prices (and forward prices if available) along with forecasts of future demand to make their production plans, which supplemented by the activities of commodities speculators ensures that future demand is met (Coase \& Fowler, 1937; Muth, 1961).

Market competition complicates an individual producer's decision fundamentally. Although aware of their own production opportunities and those of some local competitors, producers learn that they cannot accurately predict market outcomes, and hence, their fortunes. Competition gives entrepreneurs very strong incentives to discover new ways to make the same products more cheaply or make new higher quality products (Sowell, 1980). That is, producers trade off the net benefits of exploiting existing technologies, imitating competitors' innovations, and exploring and implementing altogether new production techniques. The more intense the competition (i. e. the harder current competitors and potential entrants are trying to innovate), the more important it is to discover and accurately assess new opportunities to keep the organization viable (Hayek, 1968). ${ }^{3}$ At the same time, competition between current and potential employees in the market sector ensures that firms can use incentive schemes to motivate current employees to work more effectively. "Thus, market competition allows profitable firms to grow and causes unprofitable ones to wither, forcing them to produce something different" (Coase \& Wang, 2012, p. 71).

Firms are more than just groups of individuals and can only compete against specialized individual producers by reducing overall contracting costs (Coase, 1937). As islands of planning in a market economy, firms do not use market prices to guide internal transactions, since that would assume away any competitive advantage versus specialized individual producers. Ball (1989) conceives of a firm as "a specialist contracting intermediary, intermediating between consumers and suppliers of factors of production, exploiting scale economies in repetitive contracting by centralizing contracting in one institution. Firms engage in non-market contracting, on their own internal terms (here labeled "quasi-prices"). These are not market prices and need not resemble market prices in either form or magnitude; and market prices are not sufficient to guide firms' decisions." Further, "accounting is viewed as a specialist function for providing information that assists firms in establishing their quasi-prices, or even for providing the quasi-prices themselves."

Similarly, Sunder (1997, p. 1) argues, "We can think of each organization as a set of contracts among employees, customers, managers, shareholders, suppliers, auditors, etc. Each party seeks its goals through exchange of resources with the organization. Accounting helps implement and enforce this contract set by tracking resource inflows and outflows, furnishing information about fulfillment of contracts by various parties, distributing information to attract new participants in the organization, and by making some information public to reduce the risk of conflict and deadlock at the time of contract renegotiation." Biondi (2005), Ijiri (1983), Jensen (1983), Watts and Zimmerman (1986) and others make similar arguments.

The next three sections explore what information internal quasi-prices should contain to enable more profitable decisions and greater contracting efficiency and how traditional accounting principles can help produce this information for managers and other parties.

\section{Opportunity cost}

Standard decision theory prescribes that we identify all potential solutions to a problem, compare the net value (benefits less costs) of each solution, and choose the solution with the highest expected net value. The net value of the second highest ranked option constitutes the opportunity cost of the chosen option, and represents the value of the best option forgone when making mutually exclusive choices. Importantly, the net value or net benefit of an option is not restricted to the tangible products foregone or their monetary exchange values, but also includes implicit lost time, pleasure, or anything else that provides utility to the decision maker(s). Active consideration of opportunity costs helps ensure that scarce resources are used efficiently, which in turn increases economic profit for a firm or net surplus for a society. ${ }^{5}$

Given the long history of the opportunity cost concept, it has been described as "simple, straightforward and widely understood" (Buchanan, 1987, p. 719). ${ }^{6}$ However, it turns out to be quite subtle and often misunderstood. 
Ferraro and Taylor (2005) surveyed 199 economists and Ph.D. students at the Allied Social Science Associations (ASSA) annual meeting to test their understanding of opportunity cost using this multiple choice question:

You won a free ticket to see an Eric Clapton concert (which has no resale value). Bob Dylan is performing on the same night and is your next-best alternative activity. A ticket to see Dylan will cost $\$ 40$. On any given day, you would be willing to pay up to $\$ 50$ to see Dylan. Assume there are no other costs of seeing either performer. Based on this information, what is the opportunity cost of seeing Eric Clapton? A \$0, B \$10, C \$40, D \$50.

Ferraro and Taylor (2005) argue that the net value of seeing Dylan is $\$ 10$ ( $\$ 50$ utility less $\$ 40$ ticket price), which by definition is the opportunity cost of seeing Eric Clapton, since seeing Dylan is your next-best alternative. The tallies of the economists' survey responses were A: 50, B: 43, C: 51 , D: 55 , i. e., almost randomly distributed. Even worse, the economists chose the correct answer B the least often. Poor training was not an issue since 83 economists had earned their doctorates at "top 30" economics schools, while 120 had taught the economics principles course. The survey results show that the opportunity cost concept is ambiguous. The same scenario was used in a survey of 358 undergraduate economics students, 76 percent of whom had already taken an economics class. Only $7.4 \%$ (17.2\%) of students who had previously taken an (no) economics class picked the correct answer B. The latter survey results show that the opportunity cost concept is not intuitive. Parkin (2016, pp. 12-13) explains that the confusion may arise from economics textbooks defining opportunity cost as either the physical quantity foregone (seeing Dylan) or the value foregone (\$10), which produce identical solutions only in competitive equilibrium (Knight, 1934, 663-664). ${ }^{7}$ Thus, the frequent wrong responses partially reflect the inconsistency in how the concept is envisioned and taught. However, this conceptual ambiguity does not undercut the importance of opportunity costs in making decisions.

As Braun (this issue) discusses, opportunity cost is used by some financial accounting theorists to justify current financial reporting standards. Specifically, when an asset is bought, its explicit opportunity cost is its entry value as measured by the cash payment or equivalent (since the opportunity cost is the value of an alternative asset the money could have been used to buy), i. e., the original historical cost. When an asset is being used in production, its explicit opportunity cost is the dollar value of its next best use, which can be estimated by its exit value, that is, the best price for which it could be sold (e. g. Ronen, 2008, p. 186), unless there is a better internal use. When a production asset is sold, its explicit opportunity cost is the present value of the net benefits it would generate if it were used in the business, which can be estimated by extrapolating the current cash flows generated using the asset, discounted to the present. For assets produced for sale (i. e. inventory), the opportunity cost is the second highest price offered by prospective buyers. Fair value accounting can be viewed as providing an ongoing estimate of the opportunity cost of using an asset, and in a zero transaction cost world, helps capital providers assess how efficiently capital is used on a period-by-period basis assuming that managers always maximize profits correctly. However, Ball (1975) observes that under perfect and complete markets, historical cost, replacement cost, realizable value and present value are identical, so debates over the best estimate are empty!

Opportunity cost is studied more deeply in managerial accounting and cost accounting, which examine how real-world managers can use accounting data (including non-financial data) to choose well. Managers operating in an ambiguous world, where discovering profitable transactions is costly, survive in competition using heuristics like satisficing behavior (Alchian, 1950; Simon, 1956). In a world with non-zero transactions costs, a uniform reporting period is less relevant to managers than the product-specific operating and trade cycles, which are their true decision-making periods. Managers seek to recover through sales more than the resources consumed in production, since a firm that continually loses money will fail. Managers must match against a sale all costs incurred to generate the sale so that the net benefit can be estimated and compared to those generated from other products. A common monetary unit makes it easier to compare multiple transactions using different resources, and thus, opportunity cost is better measured as the value foregone (rather than the physical quantity foregone) for most managerial decisions.

\section{Accounting principles and the search for better courses of action}

We argue that an accounting system based on Historical Cost and Conservatism provides some vital survival data on opportunity costs in a costly transacting world. Accounting principles promote learning by generating outcome data on current and past explorations, which can inform the expected net benefits of future explorations. In this section, we briefly explore the roles of a few different historical layers of accounting systems: recordkeeping, bookkeeping and accounting principles.

Accounting is a process for recording transactions and summarizing their monetary consequences in financial statements (and possibly non-financial measures and statements), although only regulatory records need 
to follow specific formats. Absent regulation, individuals and firms will likely benefit from systematically classifying and organizing related transactions so as to extract meaning from them. Accounting principles guide us in how to record, classify, and summarize accounting information to construct financial statements. Byrne (1937) explains why an "accounting principle" helps managers run firms as surviving "going concerns":

The compelling character of the scientific laws of health is evident, because to disregard them in the long run literally results in death. Engineering principles have a coercive character, because to ignore them in the building of a bridge would probably result in the collapse of the bridge. Such principles are compelling in the sense that they are in effect self-enforcing; they cannot be disregarded with impunity.

The principles of accounting are also characterized by their coercive or compelling quality because inherent in accounting principles are business laws which must be obeyed if in the long run the enterprise is to survive. This does not mean, of course, that adherence to correct accounting principles is, in itself, a guarantee of business success; accounting has to do largely with the financial policies of business, and policies of sales, production, labor, and other management problems are important elements in the success or failure of a business enterprise. It should be apparent, however, that the basing of financial policies upon accounting statements which in tum are not prepared in accordance with fundamentally right accounting principles, may lead to courses of action which, if too long pursued, will adversely affect the financial health of the business. It is in this sense that the fundamental principles of accounting may be said to be coercive and self-executory. (emphasis in original)

Until the recent adoption of the asset-liability approach and the move towards Fair Value measurement by the Financial Accounting Standards Board (FASB) and International Accounting Standards Board (IASB), accounting practice in most countries was based on Historical Cost and Conservatism. Accounting records started being kept at least 10,000 years ago (Mattessich, 1987; Nissen, Damerow \& Englund, 1993; SchmandtBesserat, 1978) and perhaps as far back as 100,000 years ago (Basu, 2015; Henshilwood, d'Errico \& Watts, 2009), likely reflecting a need to remember more complex exchanges with more partners (Basu \& Waymire, 2006). These early non-written records were physical symbolic representations of agreed-upon payments in kind, which reflected a historical cost orientation in a barter economy. This long history suggests that Historical Cost is likely to be ecologically rational (Braun, this issue; Waymire \& Basu, 2007), but how and why is recording transactions at Historical Cost useful (in helping firms survive and prosper) ${ }^{8}$

As a starting point, consider the fictional Robinson Crusoe after he was shipwrecked alone on an island (Defoe, 1719). Crusoe's island is a one-man production economy, with no possibilities for trade, money or prices. Nevertheless, Crusoe finds it valuable to record in a journal (Chapter 4) his explorations of the island so that he can remember where he was more successful in finding food and hunting animals and birds. Later on he grows various food crops and domesticates animals, and records where different crops grow better or worse and during which season, which helps him produce food at a sustainable level (Chapters 5, 7). Recording the initial planting and actual harvest of his various trials lets him estimate the opportunity cost of different uses of his time and labor, and helps Crusoe plan his future activities. The journal also helps Crusoe identify which locations are infertile or otherwise unsuitable for his efforts. Even though his ink ran out in a few years (Chapter 9), Crusoe finds it useful to refer back to the journal during his 27-year sojourn. In other words, the demand for a record of past interactions with nature (e.g. lunar calendar to predict tides) could precede even the guidance for exchange transactions posited by Waymire (2009) .

The preceding discussion also helps explain why individuals attend to sunk costs, which are costs that have already been incurred and cannot be recovered. Neoclassical economics, which assumes perfect markets and no information and transaction costs, recommends forgetting all sunk costs and analyzing only future costs and benefits when making decisions. However, Baliga and Ely (2011) argue that paying attention to sunk costs is an optimal response to limited memory of all the reasons for initiating a project (that might not be recorded because they are qualitative or non-monetary), and provide experimental evidence that is consistent with their argument. ${ }^{9}$ In other words, once Robinson Crusoe's ink runs out, he uses heuristics like sunk cost to reconstruct his unrecorded choices.

After Robinson Crusoe rescues a stranger, Friday (Chapter 14), they find it beneficial to cooperate. Their close interaction facilitates mutual monitoring. However, as more strangers interact, it is harder to monitor each other continuously and detect free-riding and/or cheating in cooperative endeavors. The opportunity cost of dealing with free riders and cheaters is the net gain that could be earned by instead dealing with trustworthy partners. Basu et al. (2009) show experimentally that when individuals play an economic game simultaneously with five partners over multiple rounds, they do not reliably discriminate between trustworthy and untrustworthy partners when they cannot keep records. However, if they are allowed to keep records, participants identify and then avoid or punish uncooperative individuals more effectively, increasing gains from trades and the wealth of the mini-economy. In other words, historical records also help identify opportunity costs in arms'length economic transactions. ${ }^{10}$ Using ethnographic data, Basu, Kirk, and Waymire (2009) show that societies 
that keep (even non-written) transaction records develop larger communities with more developed markets, specialized occupations, and better economic, political, and military outcomes.

When accountants first invented writing (c. 3200 BCE), hundreds of goods were being traded, reflecting a complex economy and the emergence of the first larger settlements. Related transactions were soon recorded together on clay envelopes and tablets (Schmandt-Besserat, 1980), the earliest form of bookkeeping. Various forms of single-entry bookkeeping emerged worldwide in ancient and medieval civilizations (Littleton \& Yamey, 1956), invariably prepared on a Historical Cost basis. The oldest surviving double-entry records were created in Italy during the thirteenth and fourteenth centuries (Lee, 1977; Sangster, 2016), from where double-entry bookkeeping spread to the rest of the world over subsequent centuries (Gleeson-White, 2012).

In a modern exchange economy, recording transactions at Historical Cost likely works best when local conditions vary, or when prices vary across a given market (Stigler, 1961). For example, gasoline prices can vary considerably between locations a few miles apart, and consumers may consider whether the price savings at a discount retailer offset the time and gas costs of driving to a distant location. Similarly, shareholders would likely want to reward managers based on how well they exploit local opportunities, which would be revealed by the revenue-expense approach (Dichev, 2008). The revenue-expense approach is also crucial for fundamental analysis by legendary investors such as Benjamin Graham, Warren Buffett and Joel Greenblatt (Lee, 2014). ${ }^{11}$

In contrast, records based on Fair Values would work better when there is little local price variation so that the "market" looks like one assumed in neoclassical price theory - i. e., everyone knows the one price to conduct a given transaction. Before accounting regulation, Fair Value accounting was used mainly by mutual funds, which buy and sell securities on liquid exchanges, consistent with this argument. Indeed, unregulated hedge funds still use Fair Value accounting. But even today, closed-end mutual funds often trade at a discount or premium relative to their net asset value estimated on a Fair Value basis (Thompson, 1978), showing that Fair Value reports do not capture value for even these simplest firms. However, these discounts and premia generally disappear when closed-end funds convert to open-end status, likely because open-end funds face partial liquidation at net asset value due to fund withdrawals. In contrast, closed-end-fund shareholders can only trade with each other but not with the fund. This evidence suggests that Fair Value measurement provides a better estimate of liquidation value than going-concern value for closed-end mutual funds (Basu, 2003), but is thus less useful for tracing how and why a firm with permanently invested capital generates value as an ongoing business (Ball, 1989; Penman, 2007).

\section{Joint adaptations: Historical Cost and Conservatism}

By the early fifteenth century, double-entry bookkeeping under Historical Cost was supplemented by Conservatism in the form of asset impairments (Littleton, 1941; Penndorf, 1933). These impairments predate income taxes (Vance, 1943) and the emergence of publicly traded equity and debt securities (Basu, 2009). Thus, impairments were likely recorded for business purposes, especially since separate books were kept for property tax purposes (Vance, 1943). Just as Crusoe found it useful to record places where crop yields were lower, we believe that firms find it useful to flag unsuccessful transactions using asset impairments to avoid repeating them (or similar transactions) in the future and incurring predictable losses.

Historical Cost and Conservatism are valuable because they jointly promote discovery by entrepreneurs of feasible and desirable opportunities. Historical Cost accounting defines the set of past transactions that shapes the set of possible future transactions, while Conservatism weeds out the undesirable transactions from this set. Jointly, Historical Cost and Conservatism let a decision maker more fully specify the set of opportunities to consider in making future investments given (possibly temporary) local conditions. The efficient exploitation of local knowledge in managing the firm improves market functioning when local conditions vary across firms and through time. However, this argument only explains why these accounting principles are useful to entrepreneurs but does not explain why they are useful to firms.

If the firm is a "going concern" in a costly contracting world, then market prices do not exist for at least some of the items in the balance sheet and income statement (Ball, 1989), because firms would not exist if they could easily be substituted for using market transactions (Coase, 1937). The quasi-prices that firms use internally must differ from market prices for the firm to survive. Ball (1989) uses this argument to explain the widespread use of standard costs, overhead cost allocation, accrual accounting, depreciation that departs from "economic depreciation," and auditing. More importantly, Ball (1989) uses this framework to explain why firms use Historical Cost and Conservatism for contracting purposes. Managers often have private data about the expected net benefits from specialized assets but also have status, pay and career incentives to overstate these benefits. Parties dealing with the firm would like to be treated fairly (Ijiri, 1983) and not overpay based on biased estimates (Watts \& Zimmerman, 1986, p. 206). Assuming arms'-length transactions, Historical Cost records provide a 
floor on the benefits the manager expected when buying an asset, but does not include unverifiable gains (Ball, 1989). Auditors, who contract to provide useful data for other contracting parties, and keenly aware of managerial incentives to overstate, only use managerial data in the firm's accounts if they run against managers' interests (Ball, 1989; Gao, 2013). Auditors follow a "lower-of-cost-or-market" rule for inventories (and traded securities until recently) and accept asset write-downs but not write-ups by managers, recognizing unrealized losses but not unrealized gains in income statements. ${ }^{12}$ Thus, Historical Cost and Conservatism jointly reduce the potential agency costs arising from managers being better informed than other contracting parties. Braun (this issue) ignores the contracting use of accounting principles because he abstracts away from all stewardship, accountability and contracting issues.

\section{Implications for accounting regulation}

Our argument to this point is that the spread of better accounting principles helps firms to better adapt to changing environments and possibly more variable environments. Fortunately, double-entry accounting has evolved as a hierarchical complex system, which tend to adapt more quickly than non-hierarchical systems (Simon, 1962). Humans have adapted to a wider range of climates and environments than any comparable species through cultural transmission of knowledge (Boyd, Richerson \& Henrich, 2011). Similarly, we argue that more effective accounting enlarges the set of identified feasible (and profitable) transactions, which makes economic environments more favorable for firms. Firms "shape" their environment similar to beavers building dams or humans clearing forests.

Conversely, misguided regulation can stall or reverse the usefulness of evolved accounting. Basu et al. (2009) argue,

Accounting is likely an ecologically rational institution that coordinates economic interaction through market exchange (Waymire, 2009; Waymire \& Basu, 2007). To adapt a metaphor from Simon (1990), historical cost accounting records and today's exchange agreements are like two blades of scissors that have become increasingly effective together over time through co-evolution. Institutional changes such as 'fair value' accounting that overwrites historical records of consummated transactions and erodes the quality of memory inherent in records may make the scissors less effective unless a matching blade is produced [footnote omitted]. Contracts and regulations rely on a set of common expectations about how performance is measured, and wholesale changes to this performance measure may entail 'unintended consequences.' One ultimate consequence of less effective recordkeeping may be the decay of economic institutions responsible for wealth generation in modern developed societies. ${ }^{13}$

Consistent with this argument, nineteenth-century attempts to mandate Fair Value reporting in Germany were quickly reversed once they were found to contribute to a financial market bubble in the early 1870s (Hoffmann \& Detzen, 2013; Richard, 2005). The SEC blamed Fair Value reporting for the 1929 stock market crash and warned against its use for decades (Walker, 1992). Demerjian (2011) documents that the FASB's recent advocacy of the balance-sheet approach and Fair Value measurement was followed by a rapid decline in the use of balance-sheet-based covenants in debt contracts, consistent with the balance sheet numbers becoming less informative. Benston and Hartgraves (2002) and Benston (2006) show that Enron's adoption of Fair Value measurement in managing its businesses contributed greatly to its eventual downfall. Allen and Carletti (2008) and Plantin, Sapra, and Shin (2008) model how Fair-Value reporting can help financial crises spread across industries, presaging the recent economic crisis. Biondi (2015) uses agent-based models and experiments to demonstrate that Fair-Value measurement exacerbates speculative bubbles relative to Historical Cost. Literature reviews to date do not identify Fair-Value measurement as a major cause of the recent financial crisis (Waymire \& Basu, 2011). However, Fair-Value measurements may have induced contagion that intensified the crisis (e. g. Dontoh et al., 2017; Khan, 2011).

Even though current accounting standards for financial instruments mandate symmetric recognition of unrealized gains and losses, Badia et al. (2017) report, "firms holding higher proportions of financial instruments measured at Level 2 and 3 fair values report more conditionally conservative comprehensive income attributable to fair value measurements, consistent with firms trying to mitigate investors' discounting of the measurements." This revealed preference shows that firms find Conservative reporting better than mandatory pure Fair-Value measurement.

Two decades of empirical research show that Conservatism is correlated with better firm outcomes in many contexts (for literature reviews, see Artiach \& Clarkson, 2011; Mora \& Walker, 2015; Ruch \& Taylor, 2015). Conservatism is associated with better corporate governance (e. g. Beekes, Pope \& Young, 2004) and better investment outcomes (e. g. Bushman, Piotroski, \& Smith, 2011; Francis \& Martin, 2010), consistent with Conservatism 
aiding management of businesses. Conservatism is associated with more timely interventions by creditors following poor performance, protecting the interests of debtholders (Zhang, 2008). Conservative firms have lower cost of debt (Wittenberg-Moerman, 2008; Zhang, 2008) and lower cost of equity (e. g. Garcia Lara, Garcia Osma \& Penalva, 2011), consistent with capital markets regarding firms with prudent accounting as less risky. Conservative firms are less likely to suffer stock price crashes (Kim \& Zhang, 2016) and are sued less often by shareholders and incur lower damages when sued (Ettredge, Huang \& Zhang, 2016). Thus, empirical research is quite strongly consistent with the survival value of Conservatism.

\section{Concluding thoughts}

Braun (this issue) extends and deepens prior arguments that traditional accounting principles like Historical Cost and Conservatism reflect behavioral heuristics that have evolved to improve human survival prospects over millions of years. His important new insight is that these principles help generate new private knowledge that feeds into market prices and improves allocative efficiency. This argument helps explain the survival of Historical Cost and Conservatism from a systemic level. However, Braun (this issue) does not explain how these accounting principles benefit firms, which gave us a chance to push these arguments further.

Although opportunity cost is widely regarded as an important economic concept, it is easier to define theoretically than to apply in practice. Opportunity cost is not known or given to an entrepreneur, but must be estimated by discovering and evaluating other courses of action. Accounting principles such as Historical Cost and conditional Conservatism help entrepreneurs discover the expected net benefits of different choices by evaluating the results of similar past choices. The "sunk cost fallacy" of economic theory, which encourages forgetting of past transactions, is optimal only in perfect markets. When the environment is uncertain and knowledge scarce, ignoring the past in forecasting the future can be hugely maladaptive.

Combining accounting data from past transactions with those from ongoing transactions enables better forecasts of the profits from prospective transactions in an uncertain world. Accounting principles such as Historical Cost and Conservatism, which are consistent with brain information processing, facilitate more profitable investments (Dickhaut et al., 2010). Transactions based on better informed priors generate more informed prices that in turn lead to greater allocative efficiency and ultimately greater growth and prosperity. In contrast to our information-based argument, Braun (this issue) relies on the endowment effect to explain individuals' attention to sunk costs, and by analogy, firms' attention to Historical Cost.

However, firms exist precisely because markets are incomplete and imperfect (Coase, 1937), and thus, the internal quasi-prices used in the contracts that constitute the firm must differ from market prices, if they even exist (Ball, 1989; Sunder, 1997). Since managers are often better informed than other contracting parties, and have incentives to overstate expected profits, auditors use Historical Cost and conditional Conservatism to mitigate upward earnings management. The resulting financial statements are less biased, which improves contracting efficiency, and helps firms compete and survive in imperfect and incomplete markets. Thus, Historical Cost and Conservatism are valuable to individual entrepreneurs and capital providers as Braun (this issue) contends, but also to the other contracting parties constituting a firm, whom he ignores. Finally, the Fair Value measurement-based balance-sheet approach of accounting standard-setters, although optimal in a zero-contracting cost world, is not ecologically rational in a costly contracting world and often generates worse outcomes for entrepreneurs, firms and markets.

\section{Acknowledgments}

We thank the editors for inviting this commentary and Yuri Biondi (editor) and two anonymous reviewers for helpful comments and suggestions.

\section{Notes}

1 Traditionally, revenues are recognized when earned and realized (cash received) or realizable (likely to be received under contractual terms), so Historical Cost accounting is broader than portrayed above. Similarly, not all unrealized losses are recognized in practice, so U.S. accounting practice largely falls between the pure Historical Cost and pure Conditional Conservatism measurement bases described above. Conservatism is categorized as Unconditional (e. g. immediate expensing) or Conditional (e. g. lower or cost or market) based on whether the method uses data about new asset values (e. g. Ball \& Shivakumar, 2005; Basu 1997; 2005; Beaver \& Ryan, 2005).

2 However, Mises (1920) pointed out that if the government owned all the means of production, there could be no prices for capital goods as they would be transferred only within the government, which would reduce allocative efficiency. In addition, government-protected 
monopolies have little incentive to please customers via innovation. Hayek (1935) observed that the experts might be interested in their own welfare above the public's, in which case misaligned incentives would likely generate suboptimal outcomes (see also Mises, 1922 , pp. 157-158).

3 Garcia-Macia, Hsieh, and Klenow (2016) report that incumbents generated most of the U.S. growth over the last 40 years using data from the U.S. Longitudinal Business Database for all non-farm private businesses. Furthermore, most growth occurs from improvement of existing varieties by incumbents rather than introduction of new products by incumbents or entrants. Jones (1995) and Bloom et al. (2016) report that new ideas are becoming harder to find insofar as increasing numbers of researchers and scientists are being employed but growth and productivity rates are slowing in industrialized countries in virtually all sectors.

4 Government-protected labor unions limit worker competition by favoring seniority over merit in promotions and pay raises, and protecting incompetent workers from firing. U.S. labor unions have been exempted from taxation, antitrust laws and many state laws and are strongest in government and regulated industries such as utilities and transportation. As Hayek (1960, p. 267) observed, "We have now reached a state where [unions] have become uniquely privileged institutions to which the general rules of law do not apply." In the U.S., labor unions have discriminated against women, Chinese and black workers (e. g. Marshall, 1965). In Europe, unions control several board seats through "codetermination," which could increase efficiency by blocking managerial opportunism (Smith, 1991). German codetermination has been found to have small effects on productivity and profitability with inconsistent signs (e. g. FitzRoy \& Kraft, 2005; Gurdon \& Rai, 1990), although there are fewer industrial strikes.

5 The Wealth of Nations (Smith, 1776) begins, "The annual labour of every nation is the fund which originally supplies it with all the necessaries and conveniencies of life which it annually consumes, and which consist always either in the immediate produce of that labour, or in what is purchased with that produce from other nations."

6 Although Green (1894) introduced the label "opportunity cost," Wieser (1914), pp. 199-200 articulated a broad 'acquisitions-cost of the entrepreneur' that included not only explicit cash outlays for 'production costs' but also an interest charge for use of capital and "the entire average wages of management, which he has a right to earn in similar enterprises; for again he would consider himself the loser, if some particular activity did not yield him this income, or did not yield it fully." The opportunity cost concept underlies the Bastiat (1848) essay comparing "what is seen" or actually occurs with "what is not seen" but would have occurred if the current choice had not been made (i. e. the counterfactual). Even earlier, Franklin (1746) starts his brief essay by saying, "Remember that Time is Money. He that can earn Ten Shillings a Day by his Labour, and goes abroad, or sits idle one half of that Day, tho' he spends but Sixpence during his Diversion or Idleness, ought not to reckon That the only Expence; he has really spent or rather thrown away Five Shillings besides."

7 Parkin (2016, p. 19) argues that the value measure is ambiguous here since $\$ 50$ is your value of seeing Dylan while $\$ 40$ is the market value of seeing Dylan and "the opportunity cost" might be interpreted as one of these values of seeing Dylan rather than the net value of $\$ 10$ that Ferraro and Taylor (2005) argue is the indisputably correct answer. Ferraro and Taylor (2005, pp. 7-8) ran the survey again to check the impact of this ambiguity by changing only the last sentence of the question to, "Based on this information, what is the minimum amount (in dollars) you would have to value seeing Eric Clapton for you to choose his concert?" Even with the net value measure specified, only $44 \%$ (15 of a smaller sample of 34 ) of academic economists chose correctly.

8 Smith (2003, p. 470) describes ecological rationality as follows: "Ecological rationality uses reason - rational reconstruction - to examine the behavior of individuals based on their experience and folk knowledge, who are "naive" in their ability to apply constructivist tools to the decisions they make; to understand the emergent order in human cultures; to discover the possible intelligence embodied in the rules, norms, and institutions of our cultural and biological heritage that are created from human interactions but not by deliberate human design. People follow rules without being able to articulate them, but they can be discovered."

9 Braun (this issue) relies on the endowment effect (Thaler, 1980) to explain individuals' use of sunk costs contrary to the predictions of neoclassical economics, and then argues that Historical Cost measures sunk costs for firms. Braun (this issue) relies on prospect theory to motivate the use of Historical Cost and Conservatism instead of Fair Values, whereas we argue that limited memory is an ultimate cause of prospect theory and the attention to sunk costs.

10 Drake, Roulstone, and Thornock (2016) report that users request historical accounting reports (primarily 10-Ks, 10-Qs and 8-Ks) from EDGAR for complex firms with reporting discretion, especially after announcements of large unexpected losses and after stock price crashes. Drake, Roulstone, and Thornock (2016, p. 448) argue, "Historical accounting reports, on the other hand, no longer contain news, so their utility to investors is likely found in their ability to provide information that contextualizes and conditions information released in the current period." This conditional search for additional data to inform more difficult choices seems inconsistent with a mechanical endowment effect as postulated by Braun (this issue).

11 Lee (2014, pp. 389-390) argues that this is true because (i) accounting provides a language for forecasting, (ii) accounting provides an ex-post settling-up mechanism, and (iii) accounting information is useful for forecasting because "although the GAAP accounting numbers are related to exchange transactions that have already taken place, they provide a wealth of information for making forecasts about the future" (p. 390). Lee (2014) argues that historical data contain useful information rather than being used merely because of an endowment effect.

12 Banker, Basu, and Byzalov (2017) report that asset impairments incorporate data from multiple performance indicators in economically sensible ways such as aligning the time horizons of indicators and the useful lives of assets. Byzalov and Basu (2016) report that auditors use disaggregated internal performance data (e. g. quarterly and segment income) in their impairment decisions, which is sensible if assets are tested for impairment in a disaggregated manner at the segment level (goodwill), pool level (inventory) or at the individual level (buildings). Both papers show that auditors give additional weight to consistent negative signals (i. e. over and above their individual weights as independent negative signals) when impairing assets, so asset impairments are credible indicators of poor expected cash flows. 13 Very pertinent to our discussion here, Simon (1990, p. 7) originally wrote, "Human rational behavior (and the rational behavior of all physical symbol systems) is shaped by a scissors whose two blades are the structure of task environments and the computational capabilities of the actor." Our socioeconomic environments are riddled with uncertainty and hidden incentives, while economic agents have limited memory and computing ability.

\section{References}

Alchian, A. A. (1950). Uncertainty, evolution and economic theory. Journal of Political Economy, 58(3), 211-221.

Allen, F. \& Carletti, E. (2008). Mark-to-market accounting and liquidity pricing. Journal of Accounting and Economics, 45(2-3), 358-378.

Arrow, K. J. \& Debreu, G. (1954). Existence of an equilibrium for a competitive economy. Econometrica, 22(3), 265-290.

Artiach, T. C. \& Clarkson, P. M. (2011). Disclosure, conservatism and the cost of equity capital: A review of the foundation literature. Accounting

\& Finance, 51(1), 2-49. 
Badia, M., Duro, M., Penalva, F. \& Ryan, S. G. (2017). Conditionally conservative fair value measurements. Journal of Accounting and Economics, 63(1), 75-98.

Baliga, S. \& Ely, J. C. (2011). Mnemonomics: The sunk cost fallacy as a memory kludge. American Economic Journal: Microeconomics, 3(4), $35-67$. Ball, R. (1975). On valuation in accounting. Working paper. University of Queensland.

Ball, R. (1989). The firm as a specialist contracting intermediary: Application to accounting and auditing. Working paper. University of Rochester.

Ball, R. \& Shivakumar, L. (2005). Earnings quality in UK private firms: Comparative loss recognition timeliness. Journal of Accounting and Economics, 39(1), 83-128.

Banker, R. D., Basu, S. \& Byzalov, D. (2017). Implications of impairment decisions and assets' cash-flow horizons for conservatism research. The Accounting Review, 92(2), 41-67.

Barker, R. \& Penman, S. H. (2016). Moving the conceptual framework forward: Accounting for uncertainty. Working paper. Oxford University and Columbia University. Retrieved from https://www.caaa.ca/media/134263/2016-car-conf-session-1_stephen-penman.pdf

Barone, E. (1908). Il ministro della produzione nello stata collettivista. Giornale Degli Economisti, 37(18), 267-293. 391414 English translation (F. A. Hayek). 1935. The ministry of production in the collectivist state. In F. A. Hayek (ed.), Collectivist economic planning (pp. 245-290) London: Routledge.

Bastiat, F. (1848). What is seen and what is not seen. Bastiat, F. (Ed.), Selected essays on political economy (pp. 1-50). Irvington-on-Hudson, NY: The Foundation for Economic Education English translation (S. Cain). 1995.

Basu, S. (1997). The conservatism principle and the asymmetric timeliness of earnings. Journal of Accounting and Economics, 24(1), 3-37.

Basu, S. (2003). Discussion - The reliability of fair value versus historical cost information: Evidence from closed-end mutual funds. Journal of Accounting, Auditing and Finance, 18(1), 25-39.

Basu, S. (2005). Discussion of conditional and unconditional conservatism: Concepts and modeling. Review of Accounting Studies, 10(2/3), 311321.

Basu, S. (2009). Conservatism research: Historical development and future prospects. China Journal of Accounting Research, 2(1), 1-20.

Basu, S. (2015). Is there a scientific basis for accounting? Implications for research, practice and education. Journal of International Accounting Research, 14(2), 235-265.

Basu, S., Dickhaut, J. W., Hecht, G., Towry, K. \& Waymire, G. B. (2009). Recordkeeping alters economic history by promoting reciprocity. Proceedings of the National Academy of Sciences of the U.S.A., 106(4), 1009-1014.

Basu, S., Kirk, M. \& Waymire, G. B. (2009). Memory, transaction records, and The Wealth of Nations. Accounting, Organizations and Society, 34(8), 895-917.

Basu, S. \& Waymire, G. B. (2006). Recordkeeping and human evolution. Accounting Horizons, 20(3), 201-229.

Basu, S. \& Waymire, G. B. (2008). Has the importance of intangibles really grown? And if so, why? Accounting and Business Research, 38(3), 171190.

Basu, S. \& Waymire, G. B. (2010). Sprouse's what-you-may-call-its: Fundamental insight or monumental mistake? The Accounting Historians Journal, 37(1), 121-148.

Beaver, W. H. \& Ryan, S. G. (2005). Conditional and unconditional conservatism: Concepts and modeling. Review of Accounting Studies, 10(2-3), 269-309.

Becker, C. S. (1962). Irrational behavior and economic theory. Journal of Political Economy, 70(1), 1-13.

Beekes, W., Pope, P. F. \& Young, S. (2004). The link between earnings timeliness, earnings conservatism and board composition: Evidence from the UK. Corporate Governance: An International Review, 12(1), 47-59.

Benston, C. J. (2006). Fair-value accounting: A cautionary tale from Enron. Journal of Accounting and Public Policy, 25(4), $105-127$.

Benston, C. J. \& Hartgraves, A. L. (2002). Enron: What happened and what we can learn from it. Journal of Accounting and Public Policy, 21(3), 105-127.

Biondi, Y. (2005). The firm as an entity: Management, organization, accounting. Working Paper No. 46. Universita degli Studi di Brescia. Available at SSRN https://ssrn.com/abstract $=774764$

Biondi, Y. (2015). Accounting and the formation of share market prices over time: A mathematical institutional economic analysis through simulation and experiment. Applied Economics, 47(34-35), 3651-3672.

Bliss, J. H. (1924). Management through accounts. New York, NY: The Ronald Press.

Bloom, N., Jones, C. I., Van Reenen, J. \& Webb, M. (2016). Are ideas getting harder to find? Working Paper. MIT, Stanford University and NBER. Retrieved from http://www-leland.stanford.edu/ chadj/ldeaPF.pdf

Boyd, R., Richerson, P. J. \& Henrich, J. (2011). The cultural niche: Why social learning is essential for human adaptation. Proceedings of the National Academy of Sciences of the U.S.A., 108(Supplement 2), 10918-10925.

Braun, E. (this issue). The ecological rationality of historical costs and conservatism. Accounting, Economics and Law: A Convivium.

Buchanan, J. M. (1979). Natural and artifactual man. Buchanan, J. M. (Ed.), What should economists do? (pp. 93-112). Indianapolis, IN: Liberty Fund.

Buchanan, J. M. (1987). Opportunity cost. Eatwell, J., M. Milgate \& P. Newman (Eds.), The New Palgrave: A dictionary ofeconomics (3, pp. 718-721). New York: Palgrave Macmillan.

Bushman, R. M., Piotroski, J. D. \& Smith, A. J. (2011). Capital allocation and timely accounting recognition of economic losses. Journal of Business Finance and Accounting, 38(1/2), 1-33.

Byrne, G. R. (1937). To what extent can the practice of accounting be reduced to rules and standards? Journal of Accountancy, 64(5), 364-379.

Byzalov, D. \& Basu, S. (2016). Conditional conservatism and disaggregated bad news indicators in accrual models. Review of Accounting Studies, 21(3), 859-897.

Coase, R. H. (1937). The nature of the firm. Economica, 4(16), 386-405.

Coase, R. H. (1982). How should economists choose? Washington, DC: American Enterprise Institute.

Coase, R. H. (1988). The firm, the market and the law. Chicago, IL: University of Chicago Press.

Coase, R. H. \& Fowler, R. F. (1937). The pig-cycle in Great Britain: An explanation. Economica, 4(13), 55-82. 
Coase, R. H. \& Wang, N. (2012). How China became capitalist. New York, NY: Palgrave Macmillan.

Defoe, D. (1719). Robinson Crusoe. London: W. Taylor.

Demerjian, P. R. (2011). Accounting standards and debt covenants: Has the "balance sheet approach" led to a decline in the use of balance sheet covenants? Journal of Accounting and Economics, 52(1), 178-202.

Demsetz, H. (1983). The structure of ownership and the theory of the firm. Journal of Law and Economics, 26(2), 375-390.

Dichev, I. D. (2008). On the balance sheet-based model of financial reporting. Accounting Horizons, 22(4), 453-470.

Dickhaut, J. W., Basu, S., McCabe, K. A. \& Waymire, G. B. (2010). Neuroaccounting: Consilience between the biologically evolved brain and culturally evolved accounting principles. Accounting Horizons, 24(2), 221-255.

Dontoh, A., Elayan, F. A., Ronen, J. \& Ronen, T. (2012). Unfair 'fair value' in an opaque credit default swap market: How markingto-market pushed the international credit crunch. Working paper. Oxford University and Columbia University. Retrieved from https://ssrn.com/abstract $=1985833$

Drake, M. S., Roulstone, D. T. \& Thornock, J. R. (2016). The usefulness of historical accounting reports. Journal of Accounting and Economics, 61(23), 448-464.

Dye, R. A. \& Sunder, S. (2001). Why not allow FASB and IASB to compete in the US? Accounting Horizons, 15(3), 257-271.

Ettredge, M. L., Huang, Y. \& Zhang, W. (2016). Conservative reporting and securities class action lawsuits. Accounting Horizons, 30(1), 93-118.

Ferraro, P. J. \& Taylor, L. O. (2005). Do economists recognize an opportunity cost when they see one? A dismal performance from the dismal science. Contributions to Economic Analysis and Policy, 4(1). Article7, December.

Financial Accounting Standards Board [FASB]. (2008). Statement of financial accounting concepts no. 1 - objectives of financial reporting by business enterprises (as Amended). Norwalk, CT: FASB.

FitzRoy, F. R. \& Kraft, K. (2005). Co-determination, efficiency and productivity. British Journal of Industrial Relations, 43(2), $233-247$.

Francis, J. \& Martin, X. (2010). Acquisition profitability and timely loss recognition. Journal of Accounting and Economics, 49(1-2), 161-178.

Franklin, B. (1746). Advice to a young tradesman. Fisher, G. (Ed.), The American instructor: Or young man's best companion (pp. 375-377). Philadelphia: B. Franklin \& G. Fisher.

Friedman, M. (1953). The methodology of positive economics. Friedman, M. (Ed.), Essays in positive economics (pp. 3-43). Chicago: University of Chicago Press.

Gao, P. (2013). A measurement approach to conservatism and earnings management. Journal of Accounting and Economics, 55(2-3), 251-268.

Garcia Lara, J. M., Garcia Osma, B. \& Penalva, F. (2011). Conditional conservatism and cost of capital. Review of Accounting Studies, 16(2), 247271.

Garcia-Macia, D., Hsieh, C.-T. \& Klenow, P. J. (2016). How destructive is innovation? NBER. Working Paper No. 22953. Retrieved from http://www.nber.org/papers/w22953.

Cleeson-White, J. (2012). Double entry: How the merchants of Venice created modern finance. New York: W. W. Norton.

Code, D. K. \& Sunder, S. (1993). Allocative efficiency of markets with zero-intelligence traders: Market as a partial substitute for individual rationality. Journal of Political Economy, 101(1), 119-137.

Code, D. K. \& Sunder, S. (1997). What makes markets allocationally efficient? The Quarterly Journal of Economics, 112(2), 603-630.

Green, D. I. (1894). Pain-cost and opportunity-cost. The Quarterly Journal of Economics, 8(2), 218-229.

Gurdon, M. A. \& Rai, A. (1990). Codetermination and enterprise performance: Empirical evidence from West Cermany. Journal of Economics and Business, 42(4), 289-302.

Hayek, F. A. (1935). The present state of the debate. Hayek, F. A. (Ed.), Collectivist economic planning (pp. 201-243). London: Routledge.

Hayek, F. A. (1945). The use of knowledge in society. The American Economic Review, 35(4), 519-530.

Hayek, F. A. (1960). The constitution of liberty. Chicago: University of Chicago Press.

Hayek, F. A. (1968). Der wettbewerb als entdeckungsverfahren. Kieler Vorträge No. 56, University of Kiel. Translation by M. S. Snow. (2002). Competition as a discovery procedure. The Quarterly Journal of Austrian Economics, 5(3), 9-23.

Henshilwood, C. S., d'Errico, F. \& Watts, I. (2009). Engraved ochres from the Middle Stone Age levels at Blombos Cave, South Africa. Journal of Human Evolution, 57(1), 27-47.

Hirshleifer, D. \& Teoh, S. H. (2009). The psychological attraction approach to accounting and disclosure policy. Contemporary Accounting Research, 26(4), 1067-1090.

Hoffmann, S. \& Detzen, D. (2013). The regulation of asset valuation in Germany. Accounting History, 18(2), 367-389.

Ijiri, Y. (1983). On the accountability-based conceptual framework of accounting. Journal of Accounting and Public Policy, 2(2), 75-81.

Jensen, M. C. (1983). Organization theory and methodology. The Accounting Review, 58(2), 319-339.

Jones, C. I. (1995). R\&D-based models of economic growth. Journal of Political Economy, 103(4), 759-784.

Khan, U. (2011). Does fair value accounting contribute to systemic risk in the banking industry? Working paper. Columbia University. Retrieved from https://ssrn.com/abstract=1327596

Kim, J. B. \& Zhang, L. (2016). Accounting conservatism and stock price crash risk. Contemporary Accounting Research, 33(1), 412-441.

Knight, F. H. (1921). Risk, uncertainty, and profit. New York, NY: Houghton Mifflin.

Knight, F. H. (1934). The common sense of political economy (Wicksteed reprinted). Journal of Political Economy, 42(5), 660-673.

Lee, C. M. C. (2014). Performance measurement: An investor's perspective. Accounting and Business Research, 44(4), 383-406.

Lee, G. A. (1977). The coming of age of double entry: The Giovanni Farolfi ledger of 1299-1300. Accounting Historians Journal, 4(2), 79-95.

Littleton, A. C. (1941). A genealogy for “cost or market". The Accounting Review, 16(2), 161-167.

Littleton, A. C. \& Yamey, B. S. (1956). Studies in the history of accounting. Homewood, IL: Irwin.

Marshall, F. R. (1965). The negro and organized labor. New York: Wiley.

Mattessich, R. V. A. (1987). Prehistorical accounting and the problem of representation: On recent archaeological evidence of the Middle East from 8000 B.C. to 3000 B.C. Accounting Historians Journal, 14(2), 71-91.

McKenzie, L. W. (1954). On equilibrium in Graham's model of world trade and other competitive systems. Econometrica, 22(2), $147-161$. 
Mises, L. E. (1920). Die Wirtschaftsrechnung im sozialistischen Cemeinwesen. Archiv Für Sozialwissenschaft Und Sozialpolitik, 47, 86-121. English translation (S. Adler). 1935. Economic calculation in the socialist commonwealth. In F. A. Hayek (ed.), Collectivist Economic Planning (pp. 87-130). London: Routledge.

Mises, L. E. (1922). Die Gemeinwirtschaft: Untersuchungen über den Sozialismus. Germany: Verlag. English translation (J.J. Kahane). 1936. Socialism: An economic and sociological analysis, London: Jonathan Cape.

Mora, A. \& Walker, M. (2015). The implications of research on accounting conservatism for accounting standard setting. Accounting and Business Research, 45(5), 620-650.

Muth, J. F. (1961). Rational expectations and the theory of price movements. Econometrica, 29(3), 315-335.

Nissen, H. J., Damerow, P. \& Englund, R. K. (1993). Archaic bookkeeping: Writing and techniques of economic administration in the ancient Near East. Chicago, IL: University of Chicago Press Paul Larsen, Trans.

Parkin, M. (2016). Opportunity cost: A reexamination. The Journal of Economic Education, 47(1), 12-22.

Penman, S. H. (2007). Financial reporting quality: Is fair value a plus or a minus? Accounting and Business Research, 37 (Supplement), $33-44$.

Penndorf, B. (1933). Luca Pacioli, Abhandlung über die Buchhaltung 1494, ... mit einer Einleitung üuber die italienische Buchhaltung im 14 und 15. Stuttgart: Jahrhundert und Paciolis Leben und Werk.

Plantin, G., Sapra, H. \& Shin, H. S. (2008). Marking-to-market: Panacea or Pandora's box? Journal of Accounting Research, 46(2), 435-460.

Richard, J. (2005). The concept of fair value in French and German accounting regulations from 1673 to 1914 and its consequences for the interpretation of the stages of development of capitalist accounting. Critical Perspectives on Accounting, 16(6), 825-850.

Ronen, J. (2008). To fair value or not to fair value: A broader perspective. Abacus, 44(2), 181-208.

Ruch, G. W. \& Taylor, G. (2015). Accounting conservatism: A review of the literature. Journal of Accounting Literature, 34, 17-38.

Sangster, A. (2016). The genesis of double entry bookkeeping. The Accounting Review, 91(1), 299-315.

Schelling, T. C. (1978). Altruism, meanness, and other potentially strategic behaviors. The American Economic Review, 68(2), $229-230$.

Schmandt-Besserat, D. (1978). The earliest precursor of writing. Scientific American, 238(6), 50-59.

Schmandt-Besserat, D. (1980). The envelopes that bear the first writing. Technology and Culture, 21(3), 5-385.

Schumpeter, J. A. (1942). Capitalism, socialism and democracy. New York, NY: Harper.

Simon, H. A. (1956). Rational choice and the structure of the environment. Psychological Review, 63(2), 129-138.

Simon, H. A. (1962). The architecture of complexity. Proceedings of the American Philosophical Society, 106(6), 467-482.

Simon, H. A. (1978). Rational decision making in business organizations. The American Economic Review, 69(4), 493-513.

Simon, H. A. (1990). Invariants of human behavior. Annual Review of Psychology, 41(1), 1-19.

Smith, A. (1776). The wealth of nations. Chicago, IL: University of Chicago Press (Reprinted 1976).

Smith, S. C. (1991). On the economic rationale for codetermination law. Journal of Economic Behavior and Organizations, 16(3), $261-281$.

Smith, V. L. (2003). Constructivist and ecological rationality in economics. The American Economic Review, 93(3), 465-508.

Solow, R. M. (1956). A contribution to the theory of economic growth. Quarterly Journal of Economics, 70(1), 65-94.

Sowell, T. (1980). Knowledge and decisions. New York, NY: Basic Books.

Stigler, C. J. (1961). The economics of information. Journal of Political Economy, 69(3), 213-225.

Sunder, S. (1997). Accounting and the firm: A contract theory. Indian Accounting Review, 1(1), 1-19.

Sunder, S. (2004). Markets as artifacts: Aggregate efficiency from zero-intelligence traders. Augier, M. \& ]. C. March (Eds.), Models of a man: Essays in memory of Herbert A. Simon. Cambridge, MA: The MIT Press.

Sunder, S. (2011). IFRS monopoly: The Pied Piper of financial reporting. Accounting and Business Research, 41(3), 291-306.

Swan, T. W. (1956). Economic growth and capital accumulation. Economic Record, 32(2), 334-361.

Thaler, R. H. (1980). Toward a positive theory of consumer choice. Journal of Economic Behavior and Organization, 1(1), 39-60.

Thompson, R. (1978). The information content of discounts and premiums on closed-end fund shares. Journal of Financial Economics, 6(2-3), 151-186.

Tintner, G. (1941a). The theory of choice under subjective risk and uncertainty. Econometrica, 9(3/4), 298-304.

Tintner, G. (1941b). The pure theory of production under technological risk and uncertainty. Econometrica, 9(3/4), 305-311.

Vance, L. L. (1943). The authority of history in inventory valuation. The Accounting Review, 18(3), 219-227.

Walker, R. G. (1992). The SEC's ban on upward revaluations and the disclosure of 'current values'. Abacus, 28(1), 3-35.

Walras, L. (1874). Éléments d'économie politique pure. Paris, France: Guillaumin. English translation (W. Jaffe). 1954. Elements of pure economics, New York: Kelley.

Watts, R. L. \& Zimmerman, J. L. (1986). Positive accounting theory. Englewood Cliffs, N]: Prentice Hall.

Waymire, G. B. (2009). Exchange guidance is the fundamental demand for accounting. The Accounting Review, 84(1), 53-62.

Waymire, C. B. \& Basu, S. (2007). Accounting is an evolved economic institution. Foundations and Trends in Accounting, 2(1-2), 1-173.

Waymire, G. B. \& Basu, S. (2011). Economic crisis and accounting evolution. Accounting and Business Research, 41(3), $207-232$.

Wieser, F. (1914). Theorie der gesellschaftlichen Wirtschaft [Theory of social economics]. Tübingen: Verlag von ].C.B. Mohr. English translation (A. F. Hinrichs). 1927. Social economics. New York: Adelphi.

Wittenberg-Moerman, R. (2008). The role of information asymmetry and financial reporting quality in debt trading: Evidence from the secondary loan market. Journal of Accounting and Economics, 46(2), 240-260.

Zhang, J. (2008). The contracting benefits of accounting conservatism to lenders and borrowers. Journal of Accounting and Economics, 5(1), 2754. 